\title{
Understanding Drug Trafficking and Organized Crime in Mali
}

\author{
Traore Sekou Amadou \\ Central China Normal University, Wuhan, China \\ Email:sekamtra1@yahoo.fr
}

How to cite this paper: Sekou Amadou, T. (2019). Understanding Drug Trafficking and Organized Crime in Mali. Advances in Applied Sociology, 9, 143-152.

https://doi.org/10.4236/aasoci.2019.95012

Received: April 6, 2019

Accepted: May 27, 2019

Published: May 30, 2019

Copyright (C) 2019 by author(s) and Scientific Research Publishing Inc. This work is licensed under the Creative Commons Attribution International License (CC BY 4.0).

http://creativecommons.org/licenses/by/4.0/

\begin{abstract}
This article is a sociological analysis of the phenomenon of drug trafficking and organized crime in Mali. It seeks to understand the mechanisms of drug trafficking and organized crime. It is based on the qualitative method as the documentary analysis tool. Hybrid theory served as a model of analysis to understand drug trafficking and organized crime in Mali. Sociological analysis of the phenomenon of drugs and organized crime in Mali shows that the size of the territory, poverty and bad governance are the causes of drug trafficking and organized crime. Thus, there is a real link between drug trafficking and organized crime in Mali. Their socio-economic impacts are global, which need a global response to contain.
\end{abstract}

\section{Keywords}

Traffic, Drugs, Organized Crime

\section{Introduction}

Mali is a country of serious political turmoil in West Africa, with the emergence of the groups armed and various kinds of criminals (separatists, terrorists, Defense, etc.), whose drug trafficking constitutes the main challenge. However, the issue of drug trafficking and organized crime in Mali imposes on the first glance what knows that the "drug trafficking" and "organized crime"? But without some controversy around these concepts, we will retain the definitions given by the United Nations.

According to the United Nations, "drug trafficking" is an illicit global trade which is culture, manufacturing, distribution and sale of substances prohibited by the law. The actions taken by the United Nations on the problems associated with drug trafficking are based on three major international drug control treaties: the single convention on Narcotic Drugs of 1961 (amended in 1972), the 
convention on substances psychotropic substances of 1971 and the United Nations convention against illicit traffic of narcotic drugs and psychotropic substances of 1988.

Beyond the character controversy and controversial expressions "organized crime" or "criminal organizations", there appears a consensus among States on the need to combat the forms of delinquency. Thus, in Palermo, in December 2000 , the 120 signatories to the UN against the transnational organized crime Convention agreed to define organized criminal groups such as the "structured groups of three people or more, existing for some time and acting in concert to commit one or more serious crimes or offences established in accordance with this Convention, to make, directly or" "indirectly, a financial or other material benefit".

The notion of organized crime is original by American. For this, organized crime is a company seeking to operate outside the control of the citizens and their Government. Its action is not improvised, but is the result of conspiracy very complex, ready to get control of an entire field of activities to earn the highest possible profit. Organized crime uses the maximum of its forces to provide goods and services illegal, to promote banned games and encourage consumption of some products. In addition, this vision of the crime organized the criminologist Canadian Jean-Paul Brodeur, who organized crime includes "illegal supply goods and services partially or totally prohibited and activities [...] illegal recycling of the benefit of these traffic" (Brodeur, 1983).

The drug trafficking and organized crime are social problems at the heart of public governance in different countries. Drug use is increasing from year to year and threatens human existence as a whole. Today, it raises a problem of public health, economic and safe. In 2015, about a quarter of a billion people were consuming drugs. Among them, about 29.5 million people or $0.6 \%$ of the world's adult population have had problems of consumption and were suffering from drugs-related disorders, including addiction. Opioids were the type of narcotic more harmful and accounted for 70 percent of the negative health impact due to drug use disorders in the world (report UNCD, 2017).

In recent years, although drug trafficking is not new in the Sahel, particularly in Mali today takes a significant proportion. Complicity at the highest level, multiplicity of actors, capacity of the stream to move into neighboring countries where the fight against the scourge is pressing (Antil, 2012). In December 2013, when the United Nations Security Council, the Secretary-General estimated the annual value of cocaine flowing through the West Africa to 1.25 billion USD. Thus, complements the annual seizures of tramadol in sub-Saharan Africa from $300 \mathrm{~kg}$ to more than 3 tons in 2013. Additional information obtained by the UNODC, indicated that transnational organized crime networks transited the tramadol, produced mainly in South Asia, transits through the Gulf of Guinea to areas of the Sahel in part controlled by armed groups and terrorist organizations. All of these data in the practice of drug trafficking and crime in Mali require that 
sociologists are a matter of priority research to help decision-makers better understand the mechanisms of its construction social.

Furthermore, it is important to note that Mali, long regarded as a country of transit, today a consumption increased drugs and drugs of any kind. According to UNODC estimates, 207,400 deaths have been linked to drugs in 2014. Drug use is a growing public health problem, and more precisely represents a scourge in the prison in Mali. In this, the drug trafficking and organized crime are two interconnected phenomena. Drug trafficking fuels crime in all its forms. A particularly alarming fact for United Nations dating back to the month of September 2017, is the seizure of more than 3,000,000 tramadol tablets, packaged in cartons bearing the label of the United Nations. These tablets were intercepted in the Niger, in a vehicle from Nigeria and in the North of Mali (UNCD, 2017).

However, the drug trafficking and organized crime are common practices in Mali and seem to jeopardize its existence. Little sociological study has been done in this area. It is in this perspective that this article questioning the mechanisms of construction of drug trafficking and crime, organized by identifying its causes, its links to interconnection and its socio-economic impacts. It contributes to the sociological understanding of the practice of drug trafficking and organized crime in Mali, whose public leaders struggle to deal effectively.

\section{Theoretical Analysis Model and Methodology}

\subsection{Theoretical Analysis Model}

Several theories have contributed to the explanation of social groups in violent or deviant. Understanding the relationship between community organizing, social interaction and individual behavior have always interested social sciences, particularly sociology. Pierre Bourdieu, sociologist French who worked on violence and the dynamics of social groups, introduced the concept of "social reproduction" to explain the forms of social deviance. For him, the phenomena of violence, whatever its nature, are productions of the company. They depend on the capital which has individuals (Bourdieu \& Passeron, 1970).

The concept of social capital is increasingly used to understand the scope of the community interaction and its effects. Coleman (1988) defines social capital as the quality and depth of relationships between members of a family and a community originally. Putnam (1993) has expanded the concept to include "networks, standards and trust that facilitate coordination and cooperation for mutual benefit" (Putnam, 1993: p 2). The Group of the World Bank (2002) changed the definition to include "institutions, relationships and standards that determine the quality and quantity of interaction of a society" (World Bank, 2002: p. 1). Finally, Nikolas Rose (2000) stressed the usefulness of the capital by setting it as "networks [relationships between individuals] stock which are used to produce goods and services in society".

In addition to these approaches, the issue of drug trafficking and organized crime seems to adopt a posture of collusion of several factors, including a hybri- 
dization of the different actors (Gayraud, 2017). According to him, there are three stages of hybridization. First of all, cooperation: organizations terrorists and criminal alliances, notably for funding or weapons. This seems to be the case between traffickers and organized crime. Then, convergence: these organizations are starting to look alike and act for mimicry. Finally, the mutation: "groups become indistinct way both political and criminal". Often the traffickers and criminals are holders of political power. This nature of mutation is supported by the words of the journalist Serge Daniel Mali, author of the 2014 book "The mafias of Mali" is an example: "in fact, all the world's mafias have themselves in Mali. I would compare this to a train. The locomotive is called illegal. She leads a drug wagon, a wagon of fake currencies, other being's humans... From this point of view, each group with an Islamist veneer has a mafia to finance" (Daniel, 2014).

So the theory of hybrids, is defined as a mixture, a cooperation of several different actors maintaining links to act together is more analysis of the phenomenon of drug trafficking and crime in Mali. In this country, several criminals, trafficker groups, terrorist and often in collusion with Governments cooperate where we can talk of a hybridization of the actors. Hybrid theory was the analytical model theory whereby the mechanisms of construction of drug trafficking and organized crime in Mali were analyzed. There is a true hybrid of the groups of criminals, terrorists, drug traffickers and some State officials. This enabled the operationalization of the concept "hybrid" whose dimensions of analysis to understand the collusion and the symbiosis of several factors involved in the field of drug trafficking and organized crime in Mali.

\subsection{Methodology}

In terms of methodological perspective, the article is exclusively based on the explanatory approach, qualitative character. The information was gathered through the analysis of documents (articles, magazines, books and speech) and the stories of the actors in the fight against drug trafficking and organized crime. Scientific sites have been used for the collection of primary and secondary data on the phenomenon of drug trafficking and organized crime. Information and data analysis has concerned the causes of drug trafficking and organized crime, its links and its socio-economic impact in Mali.

\section{The Causes of Drug Trafficking and Organized Crime in Mali}

In recent years, it develops in West Africa more precisely in Mali vast networks of traffic of all kinds to the point that this country has become, over the last decade, a hub or a sanctuary for crime organized. The drug trafficking and organized crime are today one of the most pernicious sources of insecurity and one of the scourges that threaten the more social peace, the security of individuals, political stability and the economic, social and cultural country development. 
Types of drug trafficking and criminal practices contributed to the corruption that has plagued political life, undermined social values, down the economic fabric and leaded the development of this country. This state of affairs of the drug trafficking and organized crime in Mali is explained by: vulnerabilities, structural deficits, as well as the weaknesses of the State.

The vastness of the territory, as well as the length of its borders, partly uncontrolled, offer vulnerabilities. The strength of the order is very equipped and often corruptible. This is considerable assets for smugglers and gangs of criminals to operate freely. According to Raineri Luca and Galletti Chiara (2016), bad governance, weak and the reign of insecurity are both the cause and the consequence of the intensification of criminal activities in Mali. Thus, builds small inter-State and regional cooperation as a factor aggravating the drug trafficking and organized crime in this country. Unoccupied spaces, where there is two or three inhabitants $/ \mathrm{km}^{2}$, serve as strainers for smugglers and criminal gangs, applying the principle that "nature abhors vacuum". This is facilities to go and return to Europe through the Morocco, the Algeria and Egypt without being worry.

One of the vulnerabilities is the demographics of this country, more than half of the population of this country within 20 years. But this very young population in its majority is reached by chronic unemployment and endemic poverty. This state of fact pushes young people to integrate the networks of drug trafficking and organized crime in order to minimize their suffering, added to the fragility of the State manifested by its inability to provide basic social services to people, including the defense and security of citizens.

In Mali, the criminal law governing drug and organized crime is insufficient. It doesn't take into account that the offence of participation in an association of criminal or terrorist. This incomplete legal framework has, however, creates a link between organized crime and terrorism (Luca \& Chiara, 2016). The structural question arises with importance. Political governance, economic, social and cultural no longer meets the aspirations of the people. This is inherent in the internal and external investment preventing development.

One of the reasons of this phenomenon of organized crime in Mali is related to the collusion of Governments with the drug traffickers and criminal gangs. Despite efforts by the donor countries such as the United States, the France and the European Union in respect of Mali to get to grips with crime, Malian Governments have adopted a position lax in the fight against terrorism and drug traffickers. This State shows indeed that there has always been a closed between some policy makers of the Malian State and actors of organized crime.

The socio-economic situation of the majority of the people of the Sahel is largely marked by poverty, illiteracy, the low rate of school enrolment, unemployment on a large scale of youth (even graduates). The economic activities are in turn dependent on the predominance of the informal sector at the expense of the formal. This situation was strongly compromised the development of national feeling (especially in yet more youth), exposing the people, or even States 
to predation of groups and criminal networks; social conflicts, sometimes exacerbated by impunity swell this batch.

\section{Links between Drug Trafficking and Organized Crime in Mali}

The issue of drugs and organized crime is a global concern. It remains a real obstacle to the development of the country south of the Sahara. According the report of drugs from 2017, the place of the West Africa in drug trafficking continues to take important. In fact, according to this same report (2017), clues allow to assert that Al Qaeda in the Islamic Maghreb (AQIM) is involved in the trafficking of cannabis and cocaine in the Sahel. This is supported by the words of a Director of prison services in a workshop, held June 7, 2017 in Bamako: "this workshop is vitally important, because Mali is both a country of transit and destination for trafficking in narcotics and p. chemical precursors".

Drug trafficking has always been enameled crime. The strong association between drugs and crime has been sufficiently documented by the work of Johnson, Golub, \& Dunlap (2006). According to Goldstein Paul J. (1985), three reasons may explain the link between drugs and crime: 1) psychopharmacological effect of a drug can lead an individual to violent acts towards others; 2) in order to support their expensive drug use, many users turn to producing income, as robbery crime; 3) the sale of illicit drugs is outside the dominant economy where the legal system is not available to resolve disagreements leading to systemic violence on grass or as a means of punishing subordinates.

In Mali as elsewhere, drug trafficking is not separable from organized crime. Traffickers are built in the violence and are organized in real criminal group. This shows enough that the drug trade in is always accompanied by violence and crimes of all kinds. Often they use important ways to protect their drug trafficking activities. According to the observation made in Mali, it's the motorcycle flight which is becoming more and more garish because in general, the bad people attack the population under the effect of the drug. Stabbing and sometimes even using automatic pistols, they travel around different neighborhoods to make their moves. Several cases of serious injury and worse, the dead after their attacks have been reported. This sufficiently illustrates the link between the drug trafficking and organized crime. Thus, armed separatist and terrorist groups would be in connection with the activity of drugs of any kind to Europe and the United States of America. So, Mali becomes a more dangerous narcotics transit country. The different drug seizures illustrate the magnitude of this phenomenon. 2014 today, over $9 \mathrm{~kg}$ of cocaine, $12 \mathrm{~kg}$ of methamphetamine, 10 tons of cannabis and $100 \mathrm{~kg}$ of psychotropic substances were seized by the services responsible for the fight against drugs.

\section{Socio-Economic Impact of Drug Trafficking and Crime in Mali}

According to the inter-ministerial Mission of fight against drugs and addictive, 
called "drug" any psychoactive substance or psychoactive which disrupts the functioning of the system central nervous system (sensations, perceptions, moods, feelings and motor skills) or that alters the States of consciousness. The term drug covers both illicit drugs such as cannabis, heroin or cocaine than legal drugs such as nicotine, alcohol or drugs. Under this definition of drugs, everything seems to indicate that it does not allow the sustainable human development. Drug trafficking and its criminal gangs affect all spheres of human life. Violence in all its forms is the tool of drug traffickers heavily affecting the socio-economic sphere of a country.

In Mali, drug trafficking networks seem to have reached the upper echelons of the State through civil and military officials as well as at the level of the political class. According to several sources, "with internal complicity, sometimes of high level, the drug is transported through the corridors of Sahelian and Saharan, Malian including areas" (Inter de Bamako, 2013).

Moreover, the drug trafficking and organized crime generates several billion dollars in various illicit "business". "According to estimates, the transshipment of cocaine in West Africa represent between 60 and 250 tons per year, relating to total $\$ 3$ billion to $\$ 14$ billion...". In January 2008, the Malian security forces have managed to seize 750 kilograms of cocaine. This cargo alone accounted for 36 percent of Malian military budget 2007. To grow this traffic, the mafia networks irrigate the economic and social fabric by dirty money. In this situation, there is the hybridization of the actors where terrorists and armed groups in the region of the Sahel in West Africa unite today around the drug trafficking as an excellent source of financing their activities criminal. In several West African countries, in Mali in particular, feels the sneaky effects of the drug through money particularly networks mafia, systems of predation individualized, in other words the rise to power of individuals or groups of individuals. More concretely, the money is often invested in the furniture and real estate: in Kidal as to Gao, Timbuktu and Bamako, has been suddenly proliferate of luxury vehicles at the exorbitant prices for the standard of living of the owners, immense buildings incomparable costs with the regular earnings of the wealthy, private owned companies are new rich for which were hidden treasures or distant legacies (Inter de Bamako, 2013).

In recent years, the drug trafficking and organized crime is hybridized with the system of governance in Mali. Of the hostage takers, the kidnapping industry has developed a real mafia and Amadou Toumani Touré plan would have benefited. Indeed, the words of a former United States Ambassador to Mali "lifted a corner of the veil on this industry of abductions and the connections between the hostage takers and the leaders at the Summit of the Malian State". Vicki Huddleston revealed that the France has paid 17 million US dollars in 2010 to free the French hostage in a mine of uranium in Niger and that between 2004 and 2011; several countries Europeans reportedly paid for US $\$ 89$ million of Releases hostages (Inter de Bamako, 2013). If a part of these amounts is in the in- 
fluence peddling, corruption, and the purchase of political decisions, the quality of governance in Mali could not be affected. Where no doubt the laxity of the highest authorities of the State for some actors in transnational crime, including the AQIM terrorists, drug traffickers and even rebels whose strength of hits coming from Libya to great fanfare has was welcomed with arms opened by the central Government in Bamako.

This hybridization of actors in drug trafficking and organized crime today expanded within the framework of peace agreements signed between some armed groups and the Malian Government, which provides opportunities for the practice of drug trafficking and activities criminal activities in the Sahel. The financial power of the drug traffickers, the narcoterrorists and other mafia are not without consequences on the foundations of the country. At any time, these can destabilize a Government overthrow a regime change institution, create a conflict, finance a rebellion, deconstruct the economy, destroy the social fabric, and undermine the foundations of a democratic society. The most striking example in West Africa is probably that of Guinea-Bissau.

Moreover, traffic of drugs in Mali is growing with its consumption. Today the health impacts of the use of drugs in Mali remains a real public health problem. According to a study conducted in July 2015, on a sample of 500 people who use drugs by injection, $2 \%$ are contaminated by HIV/AIDS, $15 \%$ of hepatitis B and $3 \%$ of hepatitis, with a high rate of contamination of women. Thus, at a workshop for strengthening the capacity of journalists in the fight against drugs and organized crime, the representative of UNODC (Organization of the United Nations of drugs and Crime) said that studies indicate that early initiation to substances such as alcohol and cannabis psychoactive would encourage in adulthood: dependence and other harmful behaviors at the health. "There is unfortunately only the use of drugs such as tramadol, ephedrine or diazepam which are synthetic drugs, because of increasing effect of fashion among young people, both in urban than rural cities".

In view of all these impacts, we can say that the phenomenon of drug trafficking and organized crime has a global impact. It spares no sphere of human life; so, social impacts cultural, economic, political, institutional, and health.

\section{Conclusion}

In short, the phenomenon of drug trafficking and organized crime is received in Mali. Its scope is more to demonstrate for the simple reason that this country can barely exist in its foundations of sovereign State. Today, Mali is a real home or nest for bands of drug trafficking and of crime of any kind. The drug trafficking and organized crime took an important dimension to the causes of vulnerabilities that are both demographic, economic, institutional and political.

The link between drug trafficking and organized crime is very close and interdependent. Drug trafficking is being built, feeds, and converses in crime. It is important to note that in Mali the crime has a connection link with the drug 
trafficking. This led to socio-economic impacts on the society as a whole, which calls into question the State in its existence, the institutional and economic point of view. A hybridization of different criminal groups affecting the socio-economic survival of the country.

Response policy against drug trafficking and organized crime in Mali remains inadequate. This is the result of inadequate texts of laws and the lack of adequate material to deal with. Although efforts are made by the international community to defeat this scourge, the complicity of Governments with the actors of the crime remains the fundamental reason of the failure of the struggle against the activities of drug trafficking and crime organized in Mali and the Sahel. As a result, the fight against drug trafficking and organized crime must mobilize all scientific communities, but also the active involvement of the entire international community. The issue of trafficking and organized crime is global and its management process must be global.

At the end, to improve the fight against drug trafficking and organized crime in Mali, it is to train a critical mass on the issue; to create a favorable environment for support of the people addicted to drugs; stop the denial to cope with the obvious and deconstruct the current perception of the society on drug dependent users, but also the governance of the country with minimal social and economic inequalities that can explain these illegal practices of certain populations.

\section{Conflicts of Interest}

The author declares no conflicts of interest regarding the publication of this paper.

\section{References}

Antil, A. (2012). Trafic de cocaïne au sahel. Études, 10, 307-316. https://www.cairn.info/revue-etudes-2012-10-page-307.htm

Bourdieu, P., \& Passeron, J-C. (1970). La Reproduction. Paris: Editons de Minuit

Brodeur, J.-P. (1983). High Policing and Low Policing: Remarks About the Policing of Political Activities. Social Problems, 30, 507-520. https://doi.org/10.2307/800268

Coleman, J. (1988). Social Capital in the Creation of Human Capital. The American Journal of Sociology, 94, S95-S120. https://doi.org/10.1086/228943

Daniel, S. (2014). Les mafias du Mali: Trafics et terrorisme au Sahel (320 p.). Paris: Descartes \& Cie.

Gayraud, J.-F. (2017). Théorie des Hybrides, Terrorisme et crime organisé (CNRS Editions, 256 p.).

Goldstein, P. J. (1985). The Drugs/Violence Nexus: A Tripartite Conceptual Framework. Journal of Drug Issue, 39, 143-174.

https://www.webdepot.umontreal.ca/Usagers/.../Goldstein_tripartite.pdf

Inter de Bamako (2013). La drogue au cour du pouvoir ATT: La véritable raison de sa chute. Comment le Qatar et l'Arabie Saoudite sont-ils devenus les parrains de la rébellion au Mali?

Johnson, B. D., Golub, A., \& Dunlap, E. (2006). The Rise and Decline of Hard Drugs, 
Drug Markets, and Violence in Inner-City New York. In A. Blumstein, \& J. Wallman (Eds.), The Crime Drop in America (pp. 164-206). Cambridge: Cambridge University Press. https://doi.org/10.1017/CBO9780511616167.007

Luca, R., \& Chiara, G. (2016). Le crime organisé au Mali: Son impact sur une sortie pacifique du conflit.

Putnam, R. D. (1993). What Makes Democracy Work? National Civic Review, 82, 101-107. https://doi.org/10.1002/ncr.4100820204

Rose, N. (2000). Government and Control. The British Journal of Criminology, 40, 321-339. https://doi.org/10.1093/bjc/40.2.321

UNCD (2017). http://www.unodc.org/wdr2017/index.html

World Bank (2002). Millennium Development Goals 2002. 